\title{
EFFECTS OF NANOSILVER-IMPREGNATION AND ALFALFA-INTERCROPPING ON FLUID TRANSFER IN DOWNY BLACK POPLAR WOOD
}

\author{
Hamid Reza Taghiyari ${ }^{1}$
}

\begin{abstract}
Effects of alfalfa-intercropping and nanosilver-impregnation were studied here on the specific gas permeability of 10-year old Populus nigra var. betulifolia. Specimens were impregnated with a 200 ppm aqueous dispersion of silver nanoparticles under $250 \mathrm{kPa}$ pressure; the results were then compared with the un-impregnated specimens. The size range of silver nanoparticles was 10 to $80 \mathrm{~nm}$. After the initial measurement, specimens were kept in vaporized chamber for six months $\left(43 \pm 2^{\circ} \mathrm{C}\right.$, and $80 \pm 3 \%$ relative humidity); permeability was measured every month. Results showed that maximum specific longitudinal gas permeability was observed in the nanosilver-impregnated inner-wood specimens of the treatment with alfalfa $\left(1614,4 \times 10^{-13} \mathrm{~m}^{3} \mathrm{~m}^{-1}\right)$, and minimum permeability was found in the un-impregnated outer-wood specimens of the treatment without alfalfa $\left(491,7 \times 10^{-13} \mathrm{~m}^{3} \mathrm{~m}^{-1}\right)$ before the vaporization. Vaporized chamber made permeability decrease permeability at the first phases because of the absorption of water vapors and the consequent swelling; however, due to the proliferation of pits and perforation plates by fungi and molds, permeability was eventually increased. Antibacterial property of silver did not significantly decrease the growth of molds and fungi in the nanosilver-impregnated specimens.
\end{abstract}

Keywords: Alfalfa, Specific Gas Permeability, Diameter Increment, Intercropping, Populus nigra betulifolia, Vaporized Chamber.

\section{INTRODUCTION}

Poplar, as a fast-growing species, can satisfy the growing needs for solid woods; furthermore, it offers a quality raw material for wood-composite manufacturing factories because the end product will benefit from higher compression ratio. Poplar belongs to Salicaceae family. Apart from natural species, special capabilities of poplar hybrids and clones can be useful too. These improved trees grown on intensively managed plantations reach saw-timber size and are harvested at a younger age (Dickmann 2006). In the recent decades, intercropping of poplar trees with different crops was gradually increased (Chaudhry 2003). Such an agroforestry system is suitable to encourage farmers to produce wood along with their annual crop harvests. Alfalfa, a legume that fixes nitrogen in soil, is one of the best crops for agroforestry because it does not need annual plowing and sowing. The nitrogen fixing capacity of alfalfa is about $230 \mathrm{~kg}$ per hectare yearly (Taghiyari et al. 2011a). Use of nitrogen-fixing plants is one of the methods for fertilizing plantation trees (Zobel 1992). It was proved that nitrogen-fixing plants and nitrogen fertilizers have increasing effect on growth rate (DeBell et al. 2002a, DeBell et al. 2002b, Saarsalmi et al. 2006). In turn, any change in the growth pattern and growth rate of a tree may result in variation of wood properties (Zobel 1992). Permeability, as a physical property, in solid woods has significant impact on its applications and utilization in different industries (Taghiyari et al. 2012c). Many industries need to know how permeable their wood is so that they could use permeability values in decision-making processes for impregnation, drying, filtration, as well as other purposes.

\footnotetext{
${ }^{1}$ Wood Science \& Technology Dept., Shahid Rajaee Teacher Training University, Civil Engineering Faculty, Lavizan, Shabanloo St., Tehran, Iran; htaghiyari@yahoo.com Corresponding author: htaghiyari@srttu.edu

Received: 31.01 .2013 Accepted: 21.04 .2013
} 
In hardwoods, longitudinal permeability value is more important than transversal (radial and tangential) values because of vessel elements orientation along longitudinal axis of trees. As to the fact that permeability is itself influenced by porosity and capillary structure of wood (Taghiyari 2013), the present study is, therefore, aimed at finding the effects of alfalfa-intercropping on diameter increment, as well as relationships between gas permeability and vessel properties of two treatments of with and without alfalfa-intercropping. A better knowledge on the effects, as well as final diameter increment and physical properties of the wood produced, may guide to taking a better agroforestry policy and managing the forest more efficiently. Furthermore, previous studies did not consider the possible difference between permeability of the inner and outer parts of the stem; so, findings in this regard would be quite applicable for the preservation process of poles and beams.

In the meantime, nanotechnology was used in many sciences, such as fluid transfer in porous media (Dashti et al. 2012, Ghorbani et al. 2012), enhancement of antibacterial and antimicrobial effects of silver (Narashimha et al. 2011), thermal conductivity (Kang et al. 2006), heat treatment (Taghiyari 2011), filtration, wood densification (Rassam et al. 2012), shape controlling (Sadeghi and Rastgo 2012), DNA detection (Ayesh and Awwad 2012), electrodeposition, semiconductors and molecular electronics (Soltaninezhad and Aminifar 2011, Pati 2012), hydrothermal synthesis (Alemi et al. 2012), missing data (Schmidt and Chen 2012), and many others. Furthermore, mineral and metal nanoparticles such as silver and wollastonite can both facilitate the heat-transfer (Taghiyari et al. 2012a, Taghiyari et al. 2012b, Taghiyari et al. 2012c) to the inner parts of the specimens, reduce hot press time (Taghiyari and Farajpour 2013, Taghiyari et al. 2013), improve fire-resistance (Rangavar et al. 2012, Taghiyari 2012b, Haghighi et al. 2013), and increase biological resistance of wood toward wood-deteriorating fungi and wood-insects, at the same time (Yu et al. 2012). Therefore its possible effects on the permeability of poplar specimens kept in vaporized chamber would be also beneficial to the wood impregnation and preservation industry.

\section{MATERIALS and METHODS}

\section{Specimen Procurement}

The present study was conducted on trees grown in a trial set up in the winter of 1999 with one year old rooted cuttings of Populus nigra var. betulifolia in an ongoing research project at The Iranian Research Institute of Forests and Rangelands. The trees were cut in the summer, 2008. Treatments included two sets of the poplar cuttings, both with the same initial spacing at $3 \times 4 \mathrm{~m}$; the first set was intercropped with alfalfa as $\mathrm{N}$-fixing plant, and the second was without alfalfa. Three trees were selected from each treatment in such a way that their diameters at breast height were close to the mean diameter of their respected treatments. It is to be noted that due to some governmental regulations, more than three trees was not allowed to be cut; so, it was decided to select the trees close the mean diameter, so that the final results present a general mean value of the permeability properties of the trees. The planting of alfalfa was only continued for the first five years after the initial plantation of trees (that is, year 1 to year 5). For the last five years (year 6 to year 10), planting of alfalfa was discontinued. The reason why alfalfa was not planted for the last five years was due to the spread of poplar canopies that did not let enough light for the growth of the intercropped alfalfa. The alfalfa crops were harvested several times every year without plowing and sowing. To cut the permeability specimens, disks were first taken at breast height ( $1.3 \mathrm{~m}$ above the ground level) and 4 meter-height; they were then air-dried for 5 months.

\section{Gas Permeability Specimen}

Many techniques have been brought up to measure permeability in solid woods and wood-composite materials (Dermoe et al. 2012). In the present study, longitudinal gas permeability measurement apparatus was invented by the author based on the microstructure porosity of wood (Taghiyari 2012a) (Figure 1). Longitudinal specific gas permeability was determined using the falling-water volume-displacement 
method (Shi 2007). Wood specimens were taken at random from the inner-wood and outer-wood areas. In order to eliminate the influence of moisture content on permeability, the wood samples were conditioned in a conditioning chamber at $23^{\circ} \mathrm{C}$ and relative humidity of $48 \pm 2 \%$ for four weeks; the moisture content of specimens was $10 \%$ when permeability tests were carried out. A round sample with known length as well as known cross-section area in $\mathrm{m}^{2}$ is prepared to be placed in the holder of the apparatus and be tightly tide up with silicon hose and round hose clamps. The electronic time measurement device measures the time with milli-second precision. Once the time is measured, permeability values would be determined using following equations 1 and 2. Different diameter of glass tube can be easily used in the apparatus.

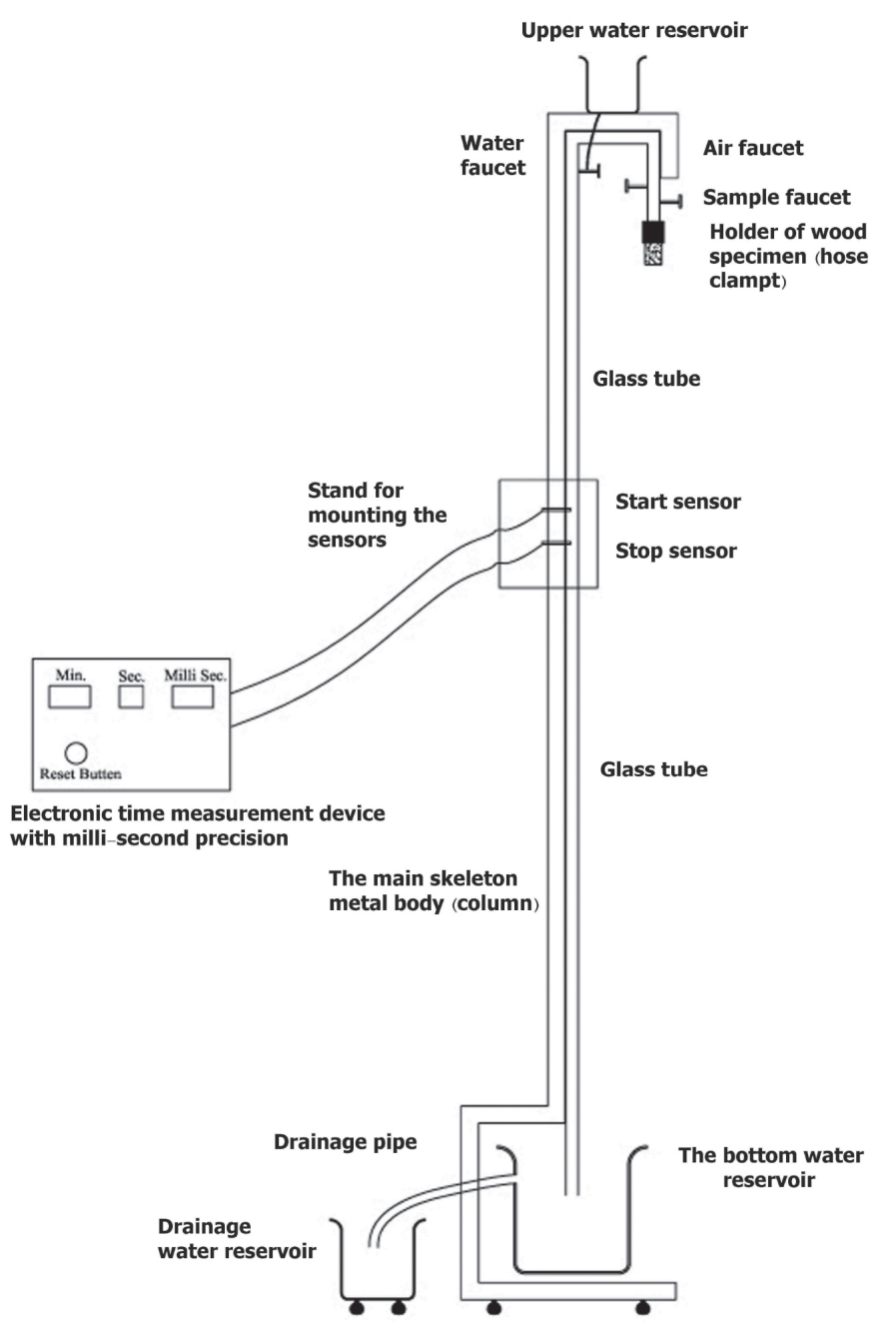

Figure 1. A schematic drawing of the gas permeability apparatus (USPTO No. US 8,079,249, B2) equipped with single-storey milli-second precision electronic time measurement device

(Taghiyari 2011b).

All gas permeability specimens were cylindrical in the present study, $18 \mathrm{~mm}$ in diameter and $30 \mathrm{~mm}$ long. Specimens were visually examined to be free from any knots, checks, and splits. The specimens were kept in conditioning chamber $\left(23^{\circ} \mathrm{C}\right.$ and relative humidity of $\left.48 \pm 2 \%\right)$ to reach MC level of $10 \%$. Both ends of each specimen were trimmed using sharp cutter blades. Furthermore, all around both longitudinal and radial specimens were covered by silicon adhesive to prevent air flow through radial and tangential directions. 20 specimens were cut randomly at scattered locations from each disk; 10 
specimens at the first five year of growth (the inner-wood specimens), and 10 specimens at the last five year of growth (the outer-wood specimens). Furthermore, 10 specimens at radial direction were also cut. Measurements were carried out using falling water displacement volume method instructions (Taghiyari and Farajpour 2013). Connection between the specimen and holder of the apparatus was made fully air-tight. A pressure gauge with milli-bar precision was connected to the whole structure to monitor pressure gradient $(\Delta P)$ and vacuum pressure at any particular time as well as height of water column. Vacuum pressures at the starting and stopping points were 112 and 101,5 (minus milli-bar), respectively.

Three measurements were taken for each specimen; the average time was used for permeability calculation. Superficial permeability coefficient was then calculated using equations 1 and 2. The superficial permeability coefficients were then multiplied by the viscosity of air $\left(\mu=1,81 \times 10^{-5} \mathrm{~Pa} \mathrm{~s}\right)$ for the calculation of the specific permeability $\left(K=k_{g} \mu\right)$.

$$
\begin{gathered}
k_{g}=\frac{V_{d} C L\left(P_{a t m}-0.074 \bar{z}\right)}{t A(0.074 \bar{z})\left(P_{a t m}-0.037 \bar{z}\right)} \times \frac{0.760 \mathrm{mHg}}{1.013 \times 10^{6} P a} \\
C=1+\frac{V_{r}(0.074 \Delta z)}{V_{d}\left(P_{a t m}-0.074 \bar{z}\right)}
\end{gathered}
$$

Where:

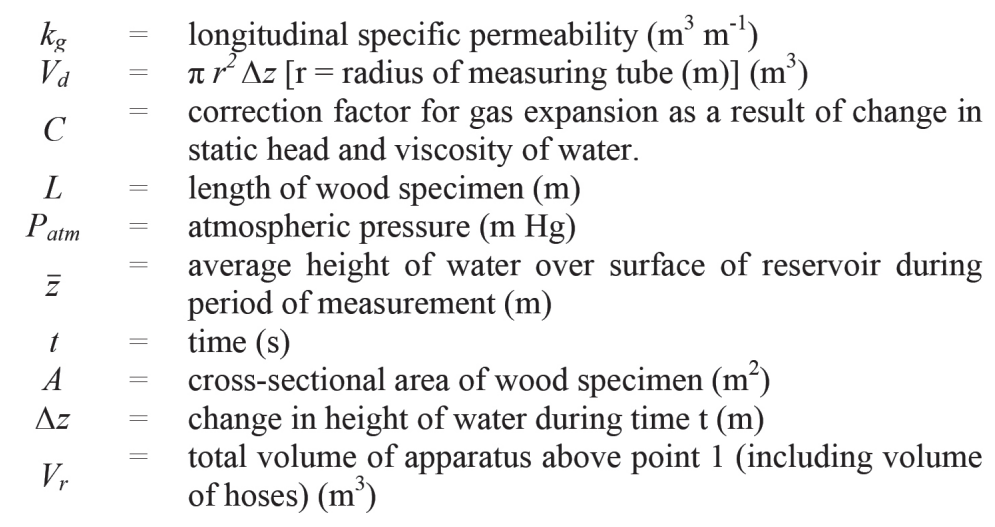

\section{Vessel Properties Measurement}

Disks were taken from the trees at breast height (1,3 m above the ground level) and then air-dried. A pith to bark strip of about $1 \mathrm{~cm}$ wide and $1,5 \mathrm{~cm}$ thick was cut along the average disc diameter; the strip was used for measuring vessel attributes. After soaking in hot distilled water for 24 hours, the strip was cut to its individual tree rings with a sharp chisel. Cross sections, $15 \mu \mathrm{m}$ thick, were cut from these samples with a sliding microtome, stained with safranine, dehydrated in a graded alcohol series, and mounted in Canada balsam C-1795 (a mounting resin medium for microscopy). Four fields in each direction (maximum and minimum growth rate directions) were selected for light microscopic analysis, and thus eight fields from each growth ring were measured. Each growth ring was subdivided into four zones from pith to bark in each direction. Each zone covered $20 \%$ of the distance between the start of the earlywood up to the end of latewood. The number of vessels in $0.4 \mathrm{~mm}^{2}$ fields was counted. The maximum and minimum VLDs (vessel lumen diameter) for all individual vessels in each field were measured and averaged. Depending on the treatment and the position of the growth ring, the number of vessels in each field varied from ca. 20-50. VLA\% (percentage of vessel lumen area) was then calculated based on VF (vessel frequency) and VLD in each field. 


\section{Nanosilver Impregnation}

A $200 \mathrm{ppm}$ aqueous dispersion of silver nanoparticles was produced using electrochemical technique. The size range of nano-suspension was 10 to $80 \mathrm{~nm}$. The $\mathrm{pH}$ of the suspension was 6- 7; two kinds of surfactants (anionic and cationic) were used in the suspension as stabilizer; the concentration of the surfactants was three times the metal nanoparticles. Empty-cell impregnation process (Rueping method) was carried out under 2,5 bar pressure for 20 minutes. After the impregnation, all the impregnated specimens were kept at room conditions $\left(30 \pm 2^{\circ} \mathrm{C}\right.$, and $45 \pm 3 \%$ relative humidity) for 4 months. Specific gas permeability values of all specimens were again measured before heat-treatment process. Due to the empty-cell impregnation process, the nano-suspension was absorbed by the cell wall and therefore the nanoparticles were stuck to the cell wall once the carrying water was evaporated. Furthermore, the high depth of penetration to the deepest parts of the specimens made the nanoparticles impossible to be wiped out by abrasion.

\section{Treatment in Vaporized Chamber}

Once all the longitudinal specimens (un-impregnated and nanosilver-impregnated) were kept together in room conditions for four months, they were put in a vaporized-chamber $\left(43 \pm 2^{\circ} \mathrm{C}\right.$, and $80 \pm 3 \%$ relative humidity). Specific gas permeability was measured every month, for six consecutive months. When the vaporized chamber was opened each month, replications of each treatment were kept in plastic bags to prevent exchange of moisture with the surrounding atmosphere; each specimen was then brought out for measurement. No precautions were made to restrain or prevent growth of molds and fungi so that not to alter the conditions in real nature.

\section{SEM Imaging}

Scanning Electron Microscope (SEM) imaging was carried out at thin-film laboratory, FE-SEM lab (Field Emission), School of Electrical \& Computer Engineering, The University of Tehran; a fieldemission cathode in the electron gun of a scanning electron microscope provides narrower probing beams at low as well as high electron energy, resulting in both improved spatial resolution and minimized sample charging and damage.

\section{Statistical Analysis}

Statistical analysis was conducted using SAS software program, version 9.2 (2008). Two-way analysis of variance (ANOVA) was performed to discern significant difference at the $95 \%$ level of confidence. Grouping was then made between treatments using the Duncan test. Hierarchical cluster analyses, including dendrogram and using Ward methods with squared Euclidean distance intervals, were carried out by SPSS/18 (2010). Regression graphs were made by Minitab software, version 16.2.2 (2010).

\section{RESULTS}

\section{Impregnation with Metal Nano-Particles}

Nano-silver adsorption was 461 and $435 \mathrm{~kg} / \mathrm{m}^{3}$ in outer-wood and inner-wood, respectively. Statistically, no clear difference was observed between NS-adsorption in the treatment with and without alfalfa.

\section{Longitudinal Gas Permeability}

Maximum specific longitudinal gas permeability was observed in the nanosilver-impregnated innerwood specimens of the treatment with alfalfa $\left(1614.4 \times 10^{-13} \mathrm{~m}^{3} \mathrm{~m}^{-1}\right)$, and minimum permeability was found in the un-impregnated outer-wood specimens of the treatment without alfalfa $\left(491,7 \times 10^{-13} \mathrm{~m}^{3}\right.$ $\mathrm{m}^{-1}$ ) before the vaporization (Figure 2). Nanosilver impregnation increased specific gas permeability in all treatments; maximum increase was found in the inner-wood specimens of the treatment with alfalfa (95,8 \% of increase). 


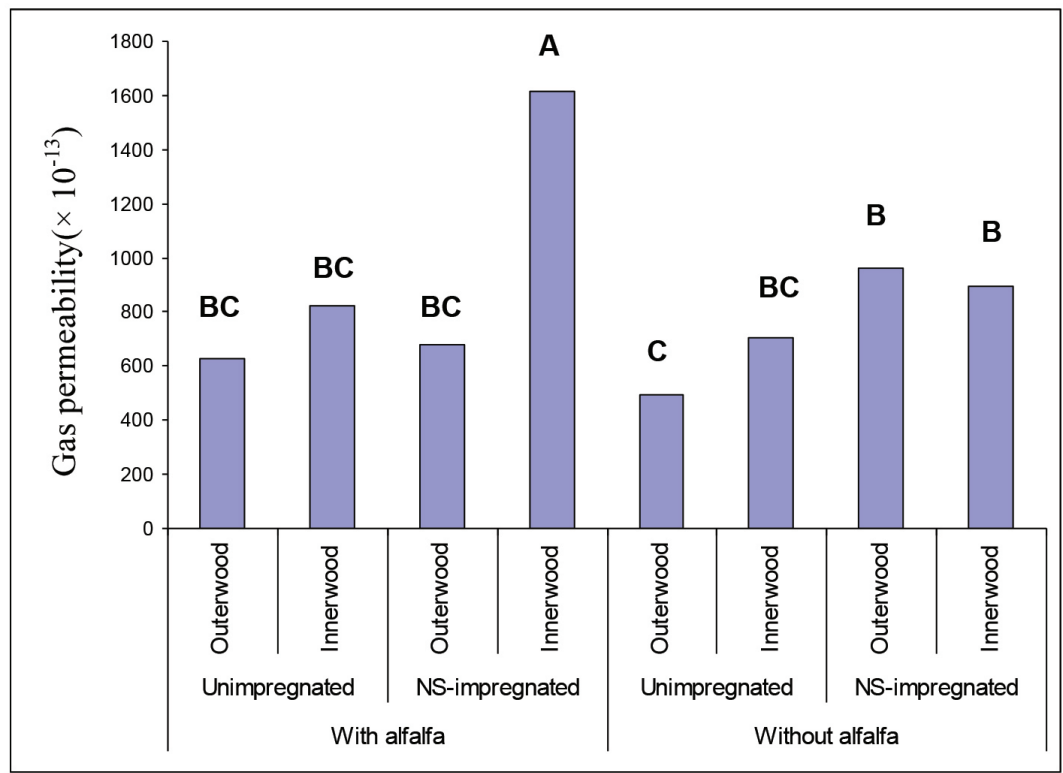

Figure 2. Specific longitudinal gas permeability values for the inner- and outer-wood in the two treatments of with and without alfalfa, both treatments with $3 \times 4 \mathrm{~m}$ initial spacing $\left(\times 10^{-13} \mathrm{~m}^{3} \mathrm{~m}^{-1}\right)$.

(NS=NanoSilver; Innerwood=wood produced in the first five years of growth; Outerwood=wood produced in the last five years of growth)

(Capital letters on each column are the Duncan groupings).

\section{Radial Gas Permeability}

Specific radial gas permeability values were significantly different in the inner and outer-woods (Figure 3). The first five years of growth (the inner-wood) showed higher permeability in both treatments of with and without alfalfa. The difference between the inner and outer-woods was higher in the treatment with alfalfa. The highest radial permeability was observed in the inner-wood of treatment with alfalfa $\left(0,364 \times 10^{-13} \mathrm{~m}^{3} \mathrm{~m}^{-1}\right)$; and the lowest permeability was $0,293 \times 10^{-13}\left(\mathrm{~m}^{3} \mathrm{~m}^{-1}\right)$, found in the outer-wood of the treatment without alfalfa.

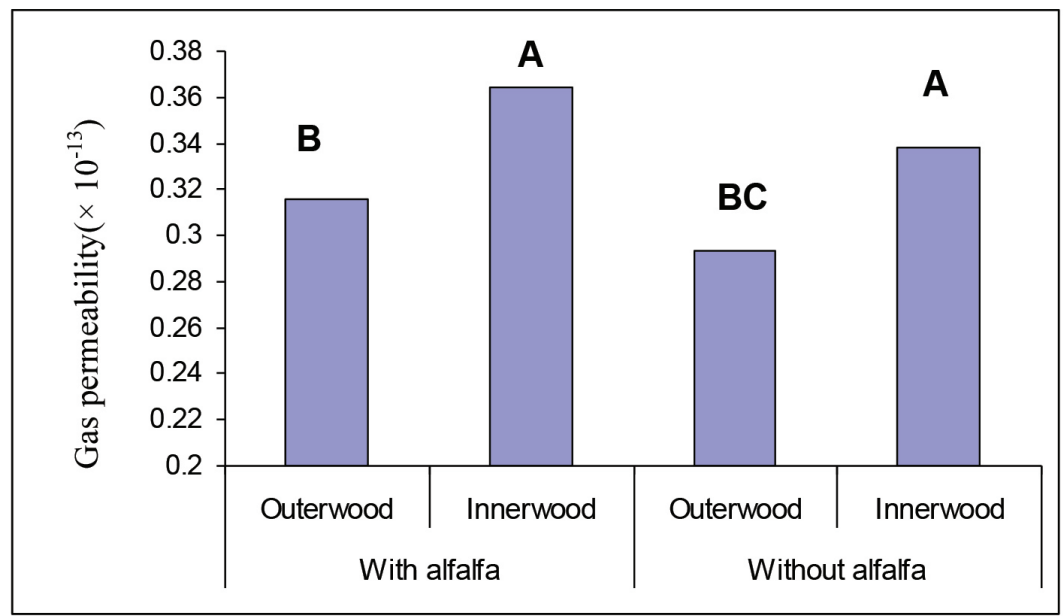

Figure 3. Specific radial gas permeability values for the inner- and outer-wood in the two treatments of with and without alfalfa, both treatments with $3 \times 4 \mathrm{~m}$ initial spacing $\left(\times 10^{-13} \mathrm{~m}^{3} \mathrm{~m}^{-1}\right)$.

(Innerwood=wood produced in the first five years of growth; Outerwood=wood produced in the last five years of growth) (Capital letters on each column are the Duncan groupings). 


\section{Vaporized Chamber}

Vaporized chamber increased gas permeability at the first phase of measurement (one month) in all treatments but the outer-wood nanosilver-impregnated specimens of the treatment without alfalfa (Figure 4). Gas permeability was then decreased in the fourth consecutive phases; in the sixth phase, gas permeability increased again.

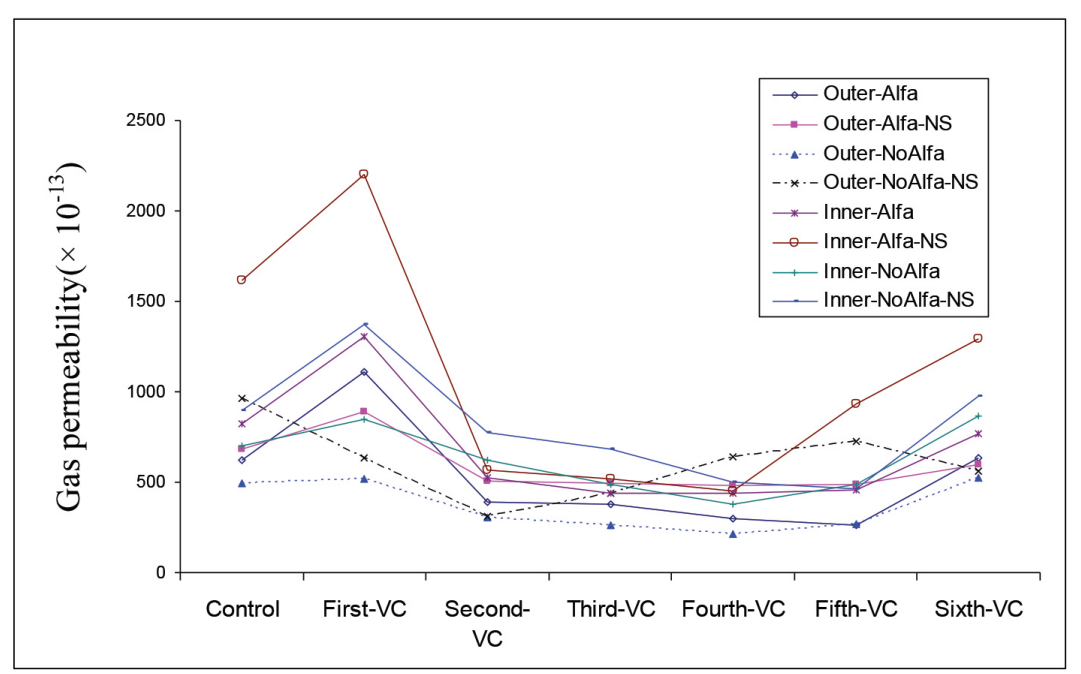

Figure 4. Specific longitudinal gas permeability values for the inner- and outer-wood in the two treatments of with and without alfalfa kept in a vaporized chamber for six months $\left(43 \pm 2^{\circ} \mathrm{C}\right.$, and $80 \pm 3 \%$ relative humidity), both treatments with $3 \times 4 \mathrm{~m}$ initial spacing $\left(\times 10^{-13} \mathrm{~m}^{3} \mathrm{~m}^{-1}\right)$.

(NS=NanoSilver; Inner=wood produced in the first five years of growth; Outer=wood produced in the last five years of growth; Alfa=treatment with alfalfa; NoAlfa=treatment without alfalfa).

\section{DISCUSSION}

Intercropping poplar trees with alfalfa, nitrogen-fertilizers, and wider initial-spacing were reported to improve vessel properties and fiber attributes (Efhami et al. 2010,2012; Taghiyari et al. 2011; Arnold and Mauseth 1999), and consequently, it generally increased gas permeability. The results of the present study approved the effects of intercropping with alfalfa on improvement of all vessel properties by alfalfaintercropping. Scatter-plots drawn between the specific gas permeability with the three vessel properties showed positive correlation between all of them (Figure 5). Significant increase was also observed in VLD (vessel lumen diameter) and VLA (vessel lumen area) of the second five year of growth of the trees; however, vessel frequency (VF) was decreased. Results also indicated that inner-wood (the first five years of growth) of both treatments had higher permeability than the outer-wood (the last five years of growth). This was in contradiction with previous studies (Taghiyari and Efhami 2011, Taghiyari et al. 2011) that reported the inner-wood (heartwood, and juvenile wood) to be less permeable than that of the outer-wood. In this connection, permeability in solid woods is considered a function of accessibility to the lumen and cell wall cavities; therefore, slight changes in the vessel properties and pit structure, and even micro-cracks and fissures in the cell wall, would result in a significant increase in the specific air permeability (Taghiyari et al. 2012c); that is, if each of the vessel properties (vessel lumen area, vessel lumen diameter, and vessel frequency) alters slightly, it would result in a significant change in the fluid transfer process in wood (Taghiyari and Efhami 2011, Taghiyari 2013). In the present study, VLD and VLA showed an increasing trend from the inner-wood to the outer-wood (Efhami et al. 2010, Efhami and Saraeyan 2009) (Table 1), therefore it was anticipated that the gas permeability would increase. However, longitudinal and radial permeability of the inner-wood (near the pith) were higher, in both 
treatments of with and without alfalfa (Figure 2 and 3). The reason was the infestation of the inner-wood with fungi during the growth of the trees. In this connection, fungi growth was reported to proliferate within the pit membranes and primary cell walls of ray parenchyma cells in pine wood, resulting in an increase in permeability of sapwood (Woo et al. 2005).

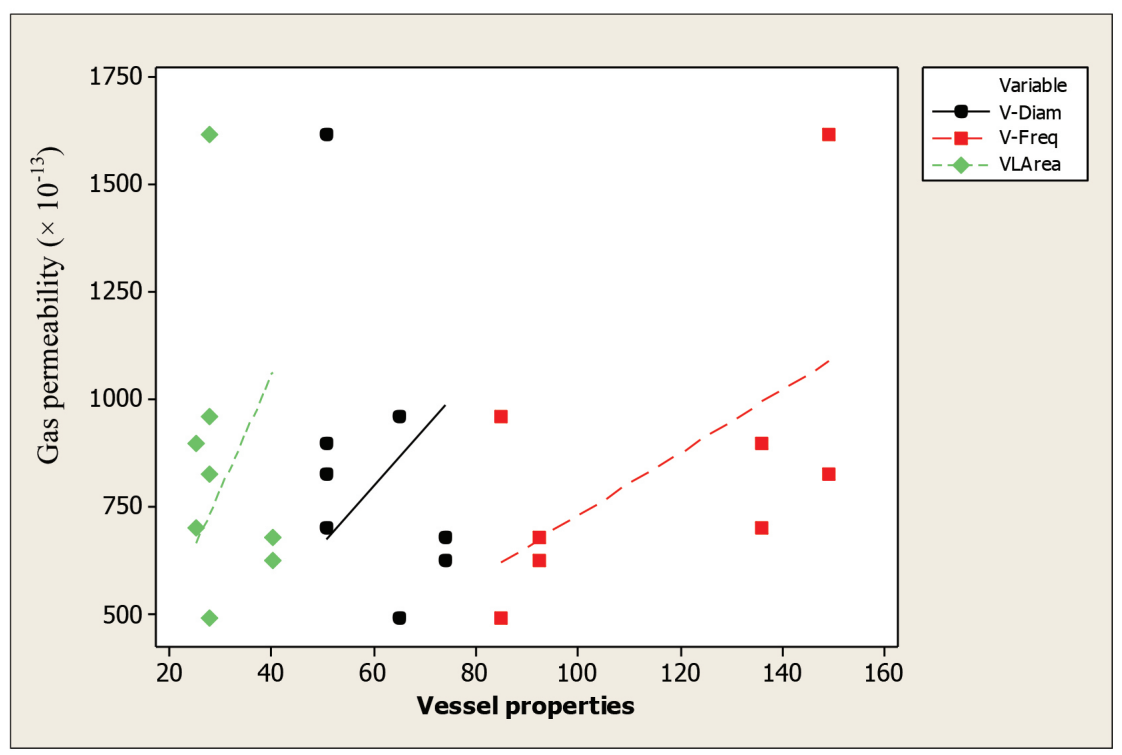

Figure 5. Scatter-plot of the specific gas permeability versus the three vessel properties of vessel diameter (V-Diam), vessel frequency (V-Freq), and vessel lumesn area (VLArea).

Table 1. Vessel properties in the inner-wood (first five years of growth) and outer-wood (second five years of growth) in the two treatments of with and without alfalfa, both with $3 \mathrm{~m} \times 4 \mathrm{~m}$ of initial spacing.

\begin{tabular}{ccccc}
\hline \hline \multirow{2}{*}{ Vessel properties } & \multicolumn{2}{c}{$\begin{array}{c}\text { Inner-wood } \\
\text { (first five years of growth) }\end{array}$} & \multicolumn{2}{c}{$\begin{array}{c}\text { Outer-wood } \\
\text { (second five years of growth) }\end{array}$} \\
\cline { 2 - 5 } & With alfalfa & Without alfalfa & With alfalfa & Without alfalfa \\
\hline \hline Vessel diameter $(\mu \mathrm{m})$ & 50,7 & 50,6 & 73,7 & 64,9 \\
\hline Vessel frequency (per mm) & 149 & 136 & 92,4 & 84,8 \\
\hline Vessel lumen area (\%) & 27,7 & 25,1 & 40,1 & 27,8 \\
\hline \hline
\end{tabular}


Nanosilver-impregnation resulted in a significant increase in the longitudinal gas permeability due to the dissolving of extractives and pitch deposits that blocked pits and perforation plates (Koch 1996, Rice and D'onofrio 1996), as well as tearing of vessel perforation plates (Taghiyari 2012a); both phenomena caused easier fluid transfer and a consequent increase in the specific gas permeability (Figure 6).

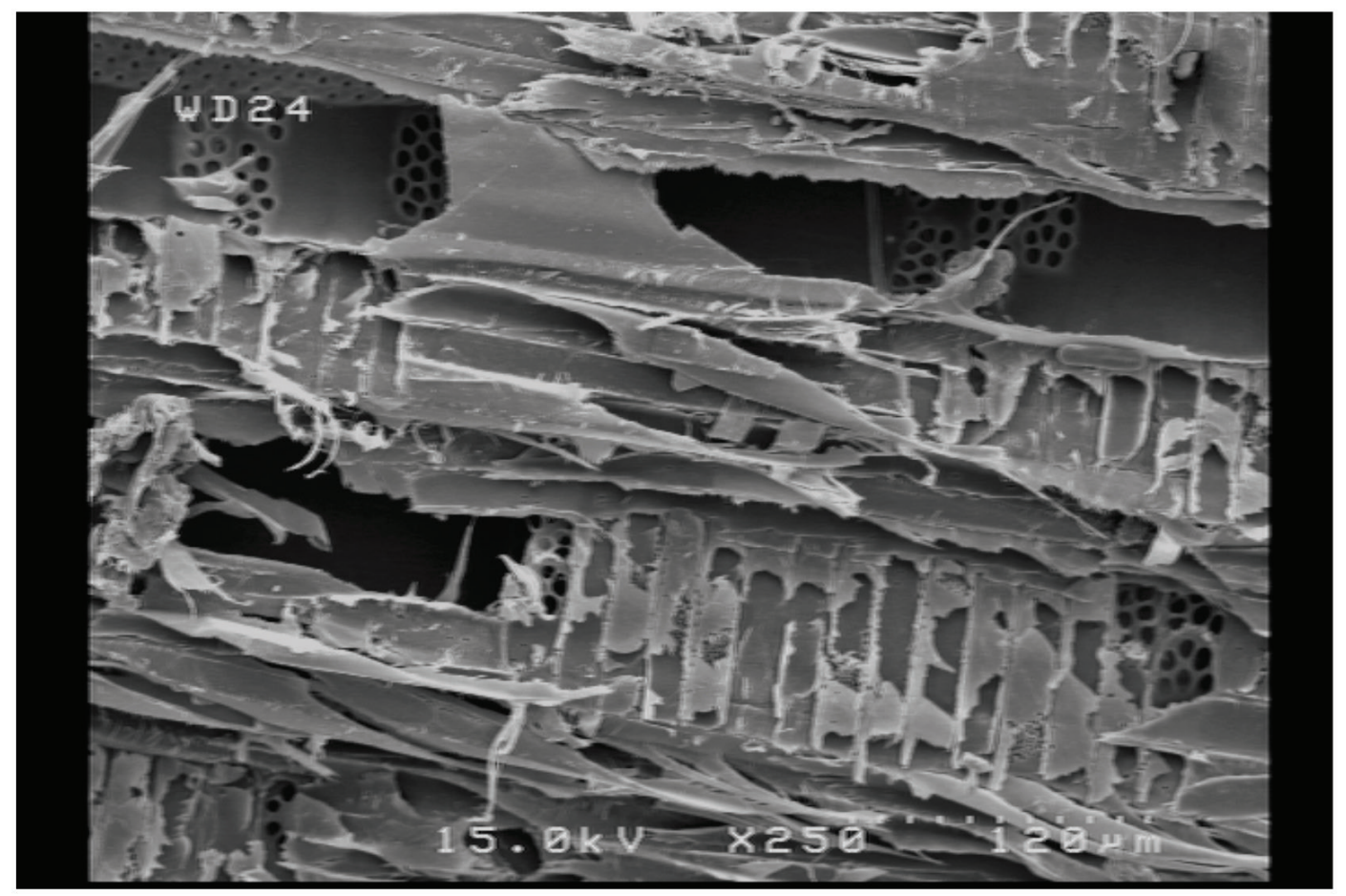

Figure 6. SEM image showing perforation plates torn out due to the high pressure in the nanosilver-impregnation vessel $(\times 250)$.

Nearly all treatments showed an increase in permeability at the first stage of vaporized chamber (Figure 4). This increase was due to the initial temperature alteration on the specimens; that is, the temperature was fixed at $43 \pm 2^{\circ} \mathrm{C}$ whereas the ambient temperature was about $22^{\circ} \mathrm{C}$. This resulted in more loss of water than gain in the specimens at the initial stages, resulting in shrinkage and wider vessels; ultimately, the fluid transfer was easier. As the process of vaporizing continued, water vapor penetrated into the specimens and absorbed by the cell wall, resulting in swelling and the consequent decrease in permeability. This process continued until the last permeability measurements (the $5^{\text {th }}$ and $6^{\text {th }}$ vaporized chamber phases) in which fungi and molds had enough time to grow and re-grow, to further deteriorate the pits and perforation plates, resulting in an increase in permeability despite of the conditions that facilitated more gain of water vapor and swelling. All treatments showed nearly the same trends in fluctuations in permeability values; this implied that the antibacterial property of silver nanoparticles that were spread through the cell walls did not show significant difference in the growth of molds and fungi (Figure 7); it may therefore be concluded that 200-ppm nanosilver dispersion can not significantly limit the deteriorating effects of molds and fungi molds and fungi in poplar. 


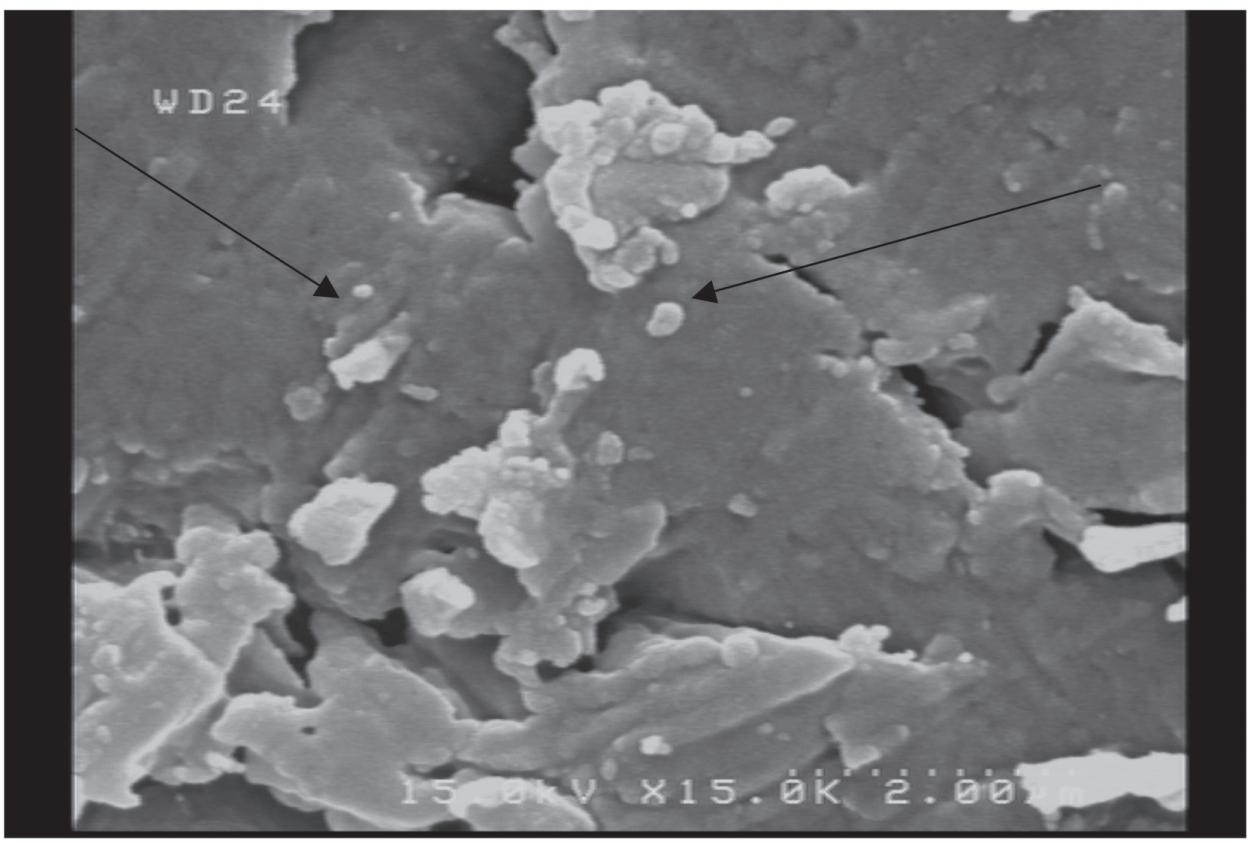

Figure 7. SEM image showing silver nanoparticles spread all over cell walls $(\times 15,000)$.

Cluster analysis based on all vessel properties and gas permeability values (at the initial stage of measurement, as well as six measurements while kept in vaporizing chamber) showed that inner- and outer-woods were clustered quite differently (Figure 8). This proves that all properties in relation with the fluid transfer in poplar wood were significantly affected by the age of the wood produced. Furthermore, in all sub-groups, control treatments and those impregnated with nano-silver suspension were closely clustered; this again may indicate that 200-ppm nanosilver can not be considered a suitable level for limitation of molds and fungi.

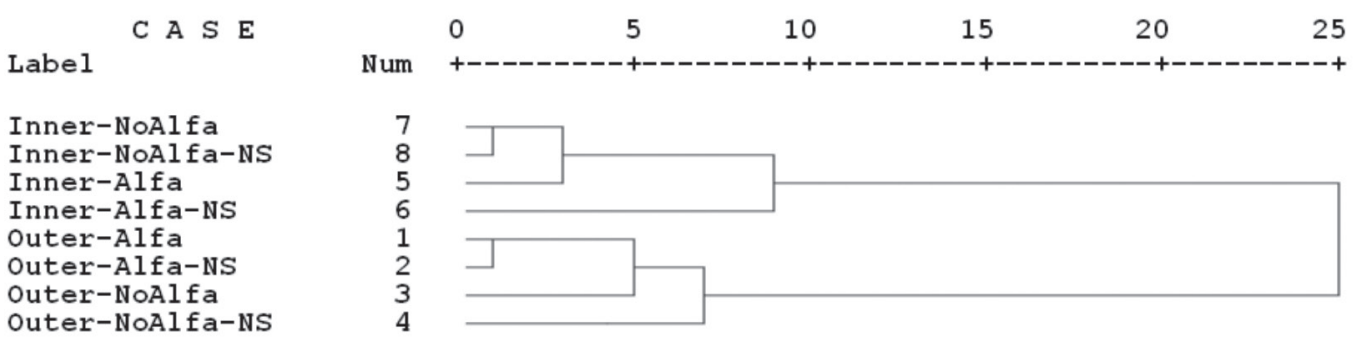

Figure 8. Cluster analysis of the eight different treatments (NS=NanoSilver; Inner=wood produced in the first five years of growth; Outer=wood produced in the last five years of growth; Alfa=treatment with alfalfa; NoAlfa=treatment without alfalfa). 


\section{CONCLUSION}

The present study confirmed that intercropping with alfalfa has an increasing effect on the specific gas permeability both in the longitudinal and radial directions of downy black poplar. This increase was due to the improvement of vessel properties caused by nitrogen enrichment in the soil of the trees intercropped with alfalfa. Furthermore, infestation by fungi during the growth of the trees proliferated pits and vessel perforations, resulting in easier transfer of fluid and higher permeability; therefore, higher permeability was observed in the first five years of growth (inner-wood) than the last five years (outerwood), although two vessel properties (vessel lumen diameter and vessel lumen area) were in favor of the outer-wood to be more permeable. Long-term vaporization of specimens also facilitates the growth or re-growth of molds and fungi, resulting in easier transfer of fluids. Intercropping with alfalfa as an $\mathrm{N}$-fixing plant may both satisfy agricultural needs as well as provide wood with higher permeability for impregnation and preservation industries. Young poplar stands are more susceptible to infestation and attack by fungi and deterioration agents. Therefore, precautions are recommended to be taken to prevent infestation by fungi during the growth of the trees, eliminating the negative effects on physical and mechanical properties of the wood produced.

\section{ACKNOWLEDGMENT}

Author is grateful to Mr. Majid Donyadide, the intelligent and active managing director of Baloot Industrial Group (Oak Industrial Group) for his great help in nanosilver impregnation process. I also pay tribute to Engines. Siavash Bayani (specialized in porous media) from Science and Research Branch of the Islamic Azad University (SRBIAU) for his magnificent contribution in analyzing the results and conclusions. Last, but surely not the least, I appreciate the help of Dr. Davood Efhami Sisi, The University of Tehran, for the technical analysis of the data.

\section{REFERENCES}

Alemi, A.; Khademinia, S.; Woo Joo, S.; Dolatyari, M.; Bakhtiari, A. 2012. Hydrothermal synthesis, characterization, optical properties Lithium Meta- and disilicate nanomaterials and theoretical calculations. International Journal of Bio-Inorganic Hybrid Nanomaterials 1(3): 137-149.

Arnold, D.H.; Mauseth, J.D. 1999. Effect of environment factors on development of wood. American Journal of Botany 86(3): 367-371.

Ayesh, A.I.; Awwad, F. 2012. Opportunity for DNA Detection using Nanoparticle-Decorated Graphene Oxide. Journal of Nanomaterials \& Molecular Nanotechnology 1:1.

Borrega, M.; Karenlampi, P.P. 2010. Hygroscopicity of Heat-Treated Norway Spruce (Picea abies) wood. European Journal of Wood Product 68:233-235.

Chaudhry, A.K. 2003. Comparative study of different densities of poplar in wheat based agroforestry system in central Punjab. PhD thesis, University of Agriculture, Faisalabad, Pakistan, 182p.

Dashti, H.; Salehpur, Sh.; Taghiyari, H.R.; Akbarifar, F.; Heshmati, S. 2012. The effect of nanoclay on the mass transfer properties of plywood. Digest Journal of Nanomaterials and Biostructures 7(3): 853-860.

DeBell, D.S.; Christopher, R.K.; Barbara, L.G. 2002a. Wood density of Eucalyptus saligna grown in Hawaiian plantations: effects of silvicultural practices and relation to growth rate. Australian Forestry 64(2): 106-110. 
DeBell, D.S.; Keyes, C.R.; Gartner, B.L. 2002b. Wood density of Eucalyptus saligna grown in Hawaiian plantations: effects of silvicultural practices and relation to growth rate. Australian Forestry 64(2): 106-110.

Dermoe, D.; Zillig, W.; Carmeliet, J. 2012. Variation of measured cross-sectional cell dimensions and calculated water vapor permeability across a single growth ring of spruce wood. Wood Science and Technology 46: 827- 840.

Dickmann, D.I. 2006. Silviculture and Biology of Short-Rotation Woody Crops in Temperate Regions: Then and Now, Department of Forestry, Michigan State Univ., East Lansing, MI 48824-1222, USA.

Efhami-Sisi, D.; Karimi, A.; Pourtahmasi, K.; Taghiyari, H.R. 2012. The effects of agroforestry practices on fiber attributes in Populus nigra var. betulifolia. Trees Structure and Function 26:435-441.

Efhami- Sisi, D.; Karimi, A.; Pourtahmasi, K.; Taghiyari, H.R.; Asadi, F. 2010. The Effects of Agroforestry Practices on Vessel Properties in Populus nigra var. betulifolia. IAWA Journal 31(4) 481- 487.

Efhami-Sisi, D.; Saraeyan, A.R. 2009. Evaluation of Anatomical and Physical Properties of Juvenile/Mature Wood of Populus alba and Populus $\times$ euramericana. Iranian Journal of Wood and Paper Science Research 24(1): 138-151.

Ghorbani, M.; Akhtari, M.; Taghiyari, H.R.; Kalantari, A. 2012. Effects of silver and zinc-oxide nanoparticles on gas and liquid permeability of heat-treated Paulownia wood. Austrian Journal of Forest Science 129(1): 106-123.

Haghighi, P.A.; Taghiyari, H.R.; Karimi, A.N. 2013. The optimum level of nano-wollastonite consumption as fire-retardant in poplar wood (Populus nigra). International Journal of Nano Dimension 4(2): 141-151.

Kang, H.U.; Kim, S.H.; Oh, J.M. 2006. Estimation of thermal conductivity of nanofluid using experimental effective particle volume. Exp Heat Transfer 19:181-191.

Koch, P. 1996. Lodgepole Pine in North America Madison, Wisconsin, Forest Products Society. USA.

Narashimha, G.; Praveen, B.; Mallikarjuna, K.; Prasad-Raju, B.D. 2011. Mushrooms (Agaricus bisporus) mediated biosynthesis of silver nanoparticles, characterization and their antimicrobial activity. International Journal of Nano Dimension 2(1): 29- 36.

Pati, R. 2012. Molecule for electronics: A myriad of opportunities comes with daunting challenges. Journal of Nanomaterials \& Molecular Nanotechnology 1:1.

Rangavar, H.; Taghiyari, H.R.; Abdollahi, A. 2012. Effects of nanosilver in improving fire-retarding properties of Borax in solid woods. International Journal of Bio-Inorganic Hybrid Nanomaterial 1(3):159-167.

Rassam, Gh.; Ghofrani, M.; Taghiyari, H.R.; Jamnani, B.; Khajeh, M.A. 2012. Mechanical performance and dimensional stability of nano-silver impregnated densified spruce wood. European Journal of Wood and Wood Products 70:595-600. 
Rice, R.W.; D'Onofrio, M. 1996. Longitudinal Gas Permeability Measurements from Eastern White Pine, Red Spruce, and Balsam Fir. Wood and Fiber Science 28(3): 301-308.

Saarsalmi, A.; Kukkola, M.; Moilanen, M.; Arola, M. 2006. Long-term effects of ash and N fertilization on stand growth, tree nutrient status and soil chemistry in a Scots pine stand. For Ecol Manage 235: 116-128.

Sadeghi, B.; Rastgo, S. 2012. Study of the shape controlling silver nanoplates by reduction process. International Journal of Bio-Inorganic Hybrid Nanomaterials 1(1): 33-36.

Schmidt, K.; Chen, B. 2012. Missing Data: A Non-ignorable issue in modern biostatistics. J Appl of Bioinform Comput Biol 1:1.

Shi, S.H.Q. 2007. Diffusion model based on Fick's second law for the moisture absorption process in wood fiber-based composites: is it suitable or not? Wood Science and Technology 41: 645-658.

Soltaninezhad, M.; Aminifar, A. 2011. Study nanostructures of semiconductor zinc oxide (ZnO) as a photocatalyst for the degradation of organic pollutants. International Journal of Nano Dimension 2(2): 137-145.

Taghiyari, H.R. 2011. Study on the Effect of Nano-Silver Impregnation on Mechanical Properties of Heat-Treated Populus nigra. Wood Science and Technology 45: 399- 404.

Taghiyari, H.R.; Efhami, D. 2011. Diameter increment response of Populus nigra var. betulifolia induced by alfalfa. Austrian Journal of Forest Science 128 (2): 113- 127.

Taghiyari, H.R.; Efhami, D.; Karimi, A.N.; Pourtahmasi, K. 2011a. Effect of initial spacing on gas permeability of Populus nigra Var. betulifolia. Journal of Tropical Forest Science 23(3): 305- 310.

Taghiyari, H.R.; Rangavar, H.; Farajpour Bibalan, O. 2011b. Nano-Silver in Particleboard. BioResources 6(4): $4067-4075$.

Taghiyari, H.R. 2012a. Correlation between gas and liquid permeabilities in some nano-silverimpregnated and untreated hardwoods. Journal of Tropical Forest Science 24(2): 249- 255.

Taghiyari, H.R. 2012b. Fire-Retarding Properties of Nano-Silver in Solid Woods. Wood Science and Technology 46(5): 939-952.

Taghiyari, H.R.; Enayati, A.; Gholamiyan, H. 2012a. Effects of nano-silver impregnation on brittleness, physical and mechanical properties of heat-treated hardwoods. Wood Science and Technology 47(3): 467-480.

Taghiyari, H.R.; Layeghi, M.; Aminzadeh Liyafooee, F. 2012b. Effects of dry ice on gas permeability of nano-silver-impregnated Populus nigra and Fagus orientalis. IET Nanobiotechnology 6(2): 40- 44 .

Taghiyari, H.R.; Rassam, Gh.; Lotfinejad Sani, Y.; Karimi, A. 2012c. Effects of nano-silver impregnation on some mechanical properties of ice-blasted specimens prepared from two native species. Journal of Tropical Forest Science 24(1): 83- 88.

Taghiyari, H.R. 2013. Effects of heat-treatment on permeability of untreated and nanosilverimpregnated native hardwoods. Maderas-Cienc Tecnol 15(2):183-194. 
Taghiyari, H.R.; Farajpour B, O. 2013. Effect of copper nanoparticles on permeability, physical, and mechanical properties of particleboard. European Journal of Wood Products 71(1): 69-77.

Taghiyari, H.R.; Mobini, K.; Sarvari Samadi, Y.; Doosti, Z.; Karimi, F.; Asghari, M.; Jahangiri, A.; Nouri, P. 2013. Effects of nano-wollastonite on thermal conductivity coefficient of medium-density fiberboard. Journal of Nanomaterials and Molecular Nanotechnology 2:1.

Woo, K.L.; Watson, P.; Mansfield, S.D. 2005. The Effects of Mountain Pine Beetle Attack on Lodgepole Pine Wood Morphology and Chemistry: Implications for Wood and Fiber Quality. Wood and Fiber Science 37(1): 112-126.

Yu, Y.; Jiang, Z.; Wang, G.; Tian, G.; Wang, H.; Song, Y. 2012. Surface functionalization of bamboo with nanostructured ZnO. Wood Science and Technology 46(4):781-790.

Zobel, B. 1992. Silvicultural effect on wood properties. IPEF International, Piracicaba (2): 31-38. 